\title{
Interfaith Dialogue in Albania as a Model of Interreligious Harmony
}

\author{
Dr. Genti Kruja ${ }^{1}$ \\ Bedër College University, Albania
}

\begin{abstract}
Over many centuries, Albanians have been mostly followers of Islam, Catholicism, and Eastern Orthodoxy. There are also other smaller religious communities, including Muslim Bektashi, Protestantism, and Judaism. Christianity and Islam, have coexisted in Albania for centuries. Tolerance is a characteristic of Albanian people, which is probably related to their geopolitical position. Being at the intersection of East and West, Albanians were influenced by both. The lands of Albanians were the meeting and division point of the two greatest empires of the Middle Ages, the Roman and the Byzantine Empires. Experiencing many vicissitudes, this peaceful co-existence, as a national value of a small nation, has continued for centuries and is still ongoing. However, a communist government lasting from 1944 to 1991 imposed a severe prohibition of the practice of religion. The interreligious cooperation during the reopening of the first church and mosque in 1990 was an expression of tolerance despite even though the communist regime was still in power. This paper presents some essential historical facts as well as a sociological approach of the interfaith understanding among Albanians.
\end{abstract}

Keywords: Albania, dialogue, interfaith co-existence, interreligious harmony, tolerance.

\section{Interfaith Dialogue in Albania as a Model of Interreligious Harmony}

Albanians are a people among whom both Abrahamic religions, Christianity, and Islam, coexist, together with their respective branches. Today, parts of the Albanian population belong to three Christian communities, the Eastern Orthodox Christianity, the Roman Catholic Western and the Protestant communities. Likewise, there are also two Islamic communities, Sunni Muslim and Bektashi. ${ }^{2}$ Albania also has atheists and believers who do not practice any specific rite and are not part of any religious community or belong to mixed families of several faiths. During the first half of the 20th century, there was also a Jewish community. Officially, Albania is a secular state, and according to the country's Constitution, Albania does not have any official religion. However, the state has not abdicated responsibility for the creation of favorable conditions for the revival and development of religion. The religious void under communism created conditions that caused, after freedom, various interferences and different goals could create discontent even within the same religion and community.

Sometimes debates arise whether the old ruins of churches belong to the Byzantine or Roman rites, should they be turned into church or mosques, or whether Albania is East or West. They can be called as sporadic or controllable acts, without impact on the basic relations between communities. Anyway, without raising the alarm, leaders of all religious communities have already

\footnotetext{
${ }^{1}$ Correspondent author: E-Mail: gkruja@beder.edu.al

${ }^{2}$ Bektashi are a branch of Sufi Islam.
} 
created the Inter-religious Council. This joint forum plans to meet periodically, in which a consistent message of peace and harmony between believers of all communities would be articulated, and their work and activities on behalf of co-existence and common future will be coordinated. Currently, five different religious communities in Albania are members of the Interreligious Council of Albania (IRCA), which was established in $2007 .^{3}$

Albanian Muslims and Christians are an example and a symbol of religious harmony in the history of Balkan nations and beyond. They have always lived in harmony and have coexisted without divisive confrontations among them; instead, they have been complementary to each other. The existence of churches and mosques close to each other proves the interfaith co-existence among Albanians. As Bruçaj (2018, p. 23) emphasized, this model of harmony, tolerance and religious co-existence in Albania makes a very positive aspect of the society's culture which has not suffered changes despite the difficulties passed during the era of the communist regime, but on the contrary, it has stood, developed and strengthened, becoming a precious identifying value of the Albanian society.

Muslims and Christians must understand once and forever that reality and destiny - not only theirs in Albania but of the whole world, from its beginning to the end represent a variety of faiths and convictions. People will have religious divisions until they believe that religions are wealth and the One God is the same for all Muslims and Christians.

Two levels of cultural interaction can be mentioned, a) the reports of Albanian subcultures influenced by the Christian and Islamic religion and b) cultural relations with neighboring nations. This kind of co-existence is found in art, architecture, language, beliefs, among others. As an illustration of such cultural intermingling, experts often study and seek explanations of the different colors dominant in Islamic art, various figures in Byzantine art, decoration of religious worship objects, external forms of residential buildings, construction style of bridges or public fountains, buildings for travelers' housing, the cross, the crescent, and the sun.

Interreligious tolerance, understanding and harmony among Albanians are one of the most distinguished values of the national culture. Sociological studies of the post-communist period have shown that besides the cultural value of loyalty and hospitality, understanding and co-existence constitute some of the most prominent profiles of the psycho-cultural modelling of Albanians throughout their history (Dervishi, 1999). Although scattered in some religious communities, they do not conflict with each other on religious issues. Albanians belong to an ethnic group, unlike Bosnia or Macedonia, where religious differences are more pronounced because of multiple ethnicities.

In Albania, religious pluralism exists, which has shown that it carries the appropriate doses of mutual tolerance. A background of inter-religious harmony also exists, which is partly inherited from the past and partly remains to be achieved thanks to the commendable work of religious communities, which try hard to preserve and develop these almost values. Many Albanian and foreign scholars have argued that religions in Albania have played a critical anti-assimilative role. For centuries, Christian and Muslim patriots have been active factors resisting the occupation and anti-denationalization policies of neighboring peoples (Dervishi, 1999).

The Albanians' multi-religious affiliation makes their national identity richer and more complex. Thus, a historical conviction was established among Albanians that all types of religious, regional, racial, genetic, national, and cultural differences were not a risk, but an asset. Such a conviction has shaped and widened the religious tolerance among the Albanians.

The religious pluralism has served as a unifying element between people, families, and various groups in society (Woofter, 2019). Religious communities remain faithful to their original

${ }^{3}$ Inter-religious Council of Albania. http://knfsh.al/en/historiku-i-knfsh-se/ 
inspiration of goodness and peace, and with dedication, and they play an active role in overcoming social problems and strengthening the family's role, culture, and national identity. Due to their contributions, all political factions of society in Albania, including religious communities, are strong supporters of integration in the European Union. Similarly, it is necessary to turn the culture of dialogue between different faiths and religious communities into a communication and exchange bridge, and into stronger links between people and communities.

From 15th to 20th centuries, the Albanian people mainly cultivated two religions, the Christian and Islamic, but the Jewish civilization was also present and is found as a decorative element of the Star of David (Kruja \& Alla, 2019). There are also pre-Christian and pre-Islamic symbols such as the sun of mythology and the crescent of Islam (Durham, 1990). Christianity and Islam normally developed in Albania during this period, and due to their expressions in the same language, they have always represented a unique voice when the protection of the national integrity was needed.

\section{Preservation of Understanding between Religious Communities among Albanians}

Albania`s president Alfred Moisiu, in his speech "Religious tolerance in the tradition of Albanian people" ${ }^{4}$ at the Oxford Forum in 2005, stated that in the 1990s Albanian emigrants were generally conveyed in a negative image in West. Yet, when politicians and scientists from the West visited the country, they found another Albania, an Albania with a European face, an Albania in which surviving civilizational values could be perceived. It was precisely this situation, this need to change the country's damaged image, to dispel the bias of the international press, which encouraged the country's researchers and their colleagues in Europe to look for positive values of the Albanian identity, an identity analogous to that of Western countries.

Societies are moving inevitably towards globalization and integration, trying to create a large family in which there is a place for all values and wealth of nations and peoples. In the global world, small countries are not expected to compete with their economies and material possessions. However, through their identity and their most precious values, they can contribute to the enrichment of global society, creating a rich mosaic of values and cultures, which recognize, respect, and develop each other. The "Albanian case," as a case of co-existence of religions during the long path of history, very soon began to be treated as the "Albanian phenomenon," which is important not only from a cultural-historical perspective but above all, as a useful experience for humanity, as a reference and an encouragement for the inter-religious communities.

Tolerance among Albanians is not only of a religious nature but also linguistic and in many cases, even ethnic. During the years of the First World War Albania, numerous foreign armies like Austrian, French, Italian, Greek, Serbian, Montenegrin, and Bulgarian forces conquered Albania. When the war ended, these armies had neither the food, medicine, nor the tools to return to their homeland. Albanian people kept them within their own families. After September 1943, when Mussolini's Italy capitulated in Albania, there were thousands of Italian militias and military officers, who had come to the country like an invading army. This army was disarmed within two weeks and then treated as deserters destined to be destroyed by the Nazi army. Italian soldiers were dressed in traditional Albanian costumes and took refuge among Albanian families. In some measure that was because tolerance was a crucial instrument for society, not only in religious but also ethnic, political and social terms (Hysa, 2020).

\footnotetext{
${ }^{4} \mathrm{http}: / /$ president.al/ (the official website of the Presidency, 9.11.2005)
} 
Another example is the Albanians' attitude towards Jews during World War II. Albanian governments, who collaborated with fascist and Nazi authorities, behaved as a vassal government, but they did not give the lists of Jews to the foreign armies. In Albania, though under double occupation, no Jew was handed over and did not end in any concentration camp. Indeed, Albania and its citizens harbored 3,000 Jews who arrived from the Balkan states, who were on the run to escape the danger of extinction from the countries in which they lived. ${ }^{5}$ These 3,000 Jews, most of whom entered illegally in Albania, found immediate and unconditional protection from the authorities and the Albanian people.

Religious communities remain faithful to their original inspirations of good and peace, and with a great devotion play an active role in overcoming social problems, socialization of youth, strengthening the role of family, culture, and national identity. Many researchers consider interfaith dialogue in Albania as an asset because there have never been religious clashes. However, recent examples in the world, but also the Balkans have shown that religious balances are very fragile and manipulations with them often have serious consequences.

Muslims and Christians have urged authorities to protect the freedom of all authorized representatives or religious leaders to fulfil their mission. They have requested the drafting of a resolution on the legal status of religious communities, as well as the re-allocation of confiscated properties during the communist system. Tolerance does not always mean empathy but does mean concerted effort to listen to and respect each other. It is mutual goodwill, recognizing the differences between people of different religions, and finally, it is the gradual shift toward compromise and consensus by all. As such, it can turn into a personal intrinsic value of people.

According to a UNDP (2018) study, "more than 90 per cent of Albanians consider religious tolerance as a fundamental value and confirm that the state does not interfere in the religious belief of the individual" (p. 75).

\section{Albanians’ Interreligious Harmony, Historical and Sociological Perspectives}

Even though there many cases of interfaith tolerance have been exhibited during centuries in Albania, in this paper presents only some of the many examples during the last two centuries. In 1858, Roman Catholic Archbishop Topich, accompanied by Dom Ejll Radovani, the vicar of Shkodra city, and other prominent priests took part in the inauguration ceremony of the commencement of the construction of the Great Catholic Cathedral. Imam Daut Boriçi, a Muslim cleric and a prominent patriot, who at that time was the director of education in Shkodra, delivered a speech on this occasion. He called the commencement of the cathedral's construction as a great joy for all Shkoder citizens regardless of their religion.

In the second half of the 19th century, the villagers of Shkreli Zone wanted to build their Catholic church, but its four villages did not agree upon the place where it should be built. The issue dragged on for a period until the village Assembly decided to build the church's foundation where Muslims inhabitants of the village would see fit, and so they did. Konica $(2001)^{6}$ emphasized "I believe that it is ubiquitously known that Albanians are tolerant toward other religions and Albania might be the only country in Europe where no religious fights have taken place" (p. 431).

In the assembly session of the League Nations Organization in 1920, the Indian delegate considering and approving Albania's acceptance in the League of Nations as a good decision,

\footnotetext{
${ }^{5} \mathrm{https}: / /$ www.youtube.com/watch?time_continue=103\&v=irBcTX1Smcw\&feature=emb_logo

${ }^{6}$ Faik Konica (1875 - 1942) was an important figure of Albanian language and culture in the early decades of the twentieth century. Ambassador of Albania in Washington. His "Albania" newspaper in US became the focal publication of Albanian writers living abroad.
} 
emphasised: While interfaith wars were still being fought in the world, in Albania, Muslims, Catholics and Orthodox were living in harmony, and the representation of a Muslim-majority country by a Christian (Orthodox) priest (Fan Noli ${ }^{7}$ ) was an excellent evidence thereof (as cited in Muja, 2009). Such examples are too many in the registers of Albanian historical documents. They did not oblige people to convert but helped them in every point of view. Frang Bardhi mentioned the help that Albanian Muslims gave in the rebuilding of the ruined Catholic church of Kabash! (Zamputi, n.d.). In Lura, the Christian priest and the imam of the mosque were invited during weddings. At Catholic weddings, the imam would be seated in the first pew, and at Muslim weddings, the priest would be seated in the front area (Ulqini, 1999, p. 30).

The American traveler, Rose Wilder Lane, talks about the house of a Catholic mountaineer of Shala, where the dinner was postponed after midnight because of the translator - Rexhep (Rajab), was a Muslim. Because in the house, they had only pork food, they sent a person to ask for other foods to another village (Lane, 1923, p. 62).

Lord Byron, who stayed at Ali Pasha Tepelena's residence in Janine, noticed that not every Albanian was Muslim; some of them were Catholics, but their religion did not make them change their behaviors and traditions. Grisebach in the 1830s also mentions the same thing, that Albanians are a population among which one cannot distinguish how many are Muslims and how many Christians just by appearance (Pirraku, 2003; Kruja 2008).

An essential event in the Albanian history of co-existence is the Prizren League. In 1878, about 300 representatives from all over Albania gathered in Prizren. The first meeting was held at the Bajrak Mosque. There were Muslim and Christian representatives in the mosque. For the North of Albania, the League Centre was Shkodra, where Albanian Catholics worked together with Muslims. "In the League, there were as many Christians as Muslims," said one of League's leaders (Knight \& Albania, 1880, p. 139).

One of the Albanian Muslim personalities was also Imam Rexhep Voka from Tetova, who also served as Mufti of Manastir city. He said: "Albanians must be united. We must not say that he is a Muslim and he is a Christian, no Toska (from South) and no Gega (from North), because all of us are Albanians, we are of the same origin" (Kaleshi, 1957, p. 378).

In the most delicate moments of the nation's history, the religious leaders, being that they had an undisputable reputation, thus, profoundly influencing the major part of the population, not only promoted religious co-existence and harmony but also they have considered the believers of different religions as their "brothers", preaching this belief to all the population (Bruçaj, 2018). It is fair to conclude that interfaith dialogue has become a regional necessity for solving problems brought about by the previous regimes and political systems in the Balkans.

The Albanians' history of interfaith tolerance and harmony has also had its own challenges. However, they have been overcome with courage and coolness. For example, in the early 20th century, some persons wanted to burn Lezha's mosque. Father Fishta ${ }^{8}$ heard about it, and then he went to the mosque. When they went to burn it, Fishta called them by names. They were surprised and asked him: "How can you be priest and imam at the same time? Fishta gave them a simple answer: "No, I am only a priest, but as the imam had some things to do in Shkodra, he asked me to look around the mosque because even this is God's house for all Albanians!" In his famous book,

\footnotetext{
${ }^{7}$ Fan Noli (1882 - 1965), was an Albanian writer, scholar, diplomat, politician, historian, orator and founder of the Orthodox Church of Albania, who served as Prime Minister and regent of Albania in 1924 during the June Revolution. ${ }^{8}$ Gjergj Fishta (1871 - 1940) was an Albanian Catholic priest. He was regarded as the national poet of Albania and one of the most influential Albanian writers of the 20th century.
} 
Fishta (1998) wrote in the name of tolerance: "I, the priest, say the truth/I sacrifice myself together with Muslims" (p. 296).

A sign of interfaith tolerance among citizens of different religions was also the fact that the Saverian College (Jesuit high school) in Shkodra, was attended not only by Catholic students but also by 159 Muslim students and 99 Orthodox students. In addition, some Muslim girls studied in a Catholic girl school. In the Muslim school, which was inaugurated in 1902, there were also Catholic students.

Vehbi Dibra the first Chair of the Assembly after independence (1912-1913) and the first Head of the Muslim Community of Albania (1923-1929) said: "Christians and Muslims are Albanian brothers undivided... to love each-other... to extend to the whole world that regardless of their religion, Albanians are brothers, the same sons of our beloved Albania" (Shpuza, 1999, p. 41). Vehbi Dibra, a Muslim leader, was also signatory to the declaration of independence (1912) (Xhelili, 1999). Sami Frashëri" declared: "Muslims, Catholics and Orthodox wherever they are, they are brothers; they are of one mind, one goal and one faith" (Shpuza, 1997, p. 41).

H. Ibrahim Kaduku ${ }^{10}$ was vice-chair of the Muslim Community, as well as the Mufti of Kavaja up to 1949. In his Friday sermon said, "We are the people of the same language and blood of the same country..." (Kruja \& Rasha, 2015, p. 88). When he took a trip, he sat nearby a priest, and they talked to each other during their entire journey.

H. Muhamed Bekteshi ${ }^{11}$ preached: "All human beings are the creation of Lord... to Him belong each of them, and to Him we are going to, and therefore we have to love each other, not to fight or have troubles but to work together for the best of our nation" (Luli \& Dizdari. 1995, p. 281). Idriz Gjilani ${ }^{12}$ pointed out: “...helping each other with writing, with words, with wealth and loving as if we were all brothers... We have three religious beliefs but just one single homeland... one language, one sun and one God. Above all, our duty is our brotherhood and protecting our homeland" (Delvina, 1998, p. 25).

During the First Independence Anniversary in Shkodra, on 28 November 1913, the whole population, Catholics, and Muslims were celebrating together. It was this night that the bell of the church was connected with a rope with that of the Mosque minaret where the Albanian flag hang.

The elderly in Shkodra said that during the month of Ramadan, the Catholic merchants in the bazaar kept their shops, especially their restaurants and bars, closed. This show the mutual respect, tolerance and interreligious harmony between Catholics and Muslims.

In Shkodra's old bazaar (one of the largest bazaars of Balkans), one of the market days was Sunday. As Sunday was a holy and significant day for Christians due to their religious rituals, the authorities decided that Wednesday and the Saturday should be the prime market days. Ombashi (2020) mentions Ilo Mitkë Qafzezi as a Christian, who was the first to translate the Qur'an into Albanian. The prohibition of religious institutions and propaganda in Albania during communist rule was a demonstration of equal maltreatment towards the three main religions. The mufti of Durres, Mustafa Varoshi and Catholic priest, Vinçens Prendushi, were placed in the same cell and tomb (Kruja, 2008).

The reopening of the first mosque and first church in Albania, in November 1990, after a quarter-of-a-century ban, was an expression of harmony and of religions confronting the communist regime, which was still in power. The Catholic and Muslim young men were co-

\footnotetext{
${ }^{9}$ Sami Şemseddin Frashëri (1850 - 1904) was an Ottoman Albanian writer, philosopher, playwright and a prominent figure of the National Renaissance movement of Albania.

${ }^{10}$ H. Ibrahim Kaduku (869 - 1949) was a prominent Muslim cleric, teacher and Albanian patriot. It is decorated with the order "Naim Frashëri of Class I".

${ }^{11}$ Mohamed Bekteshi (1883-1958), Muslim cleric.

${ }^{12}$ Idriz Gjilani (1901 - 1949) was born in Kosovo and was an Albanian patriot, a Muslim preacher and freedom fighter.
} 
workers during opening ceremonies in the church and mosque. Even though I was only thirteen then, I still remember those days, when many Catholic volunteers worked together with the Muslim volunteers. Who can say whether there were more Muslims than Catholics among the participants who attended the first sermon given by H. Sabri Koçi ${ }^{13}$ on the mosque reopening? H. Sabri Koçi's speech will remain historic because it opened the first Islamic religious ceremony after communism with the following words: "Dear Muslim, Catholic and Orthodox brothers and, above all, Albanian brothers." 14

The current Head of the Muslim Community of Albania, Bujar Spahiu, in his first speech after electing as the head of the community, stressed that he would work to strengthen interreligious dialogue (Spahiu, 2019). Albania is a multi-religious society and a Muslim majority country living in the European continent, a characteristic of importance mentioned that several political and religious world leaders have mentioned on many occasions (Gjana, 2020).

In 1993, when Pope John Paul II came to Albania, not only Catholics but also Muslims and Orthodoxies awaited him. They closed their homes and went out on the roads of Shkodra and Tirana. In his speech during the visit, Pope John Paul II said:

I wish with all my heart that this visit served to strengthen the traditional ties of fraternal coexistence that has always characterized the relations between different religions in your homeland (as cited in Frendo, 2018, p. 27).

However, a small country, Albania has been visited by two Popes within two decades. In 2014 Pope Francis, visits Albania too. In both cases, besides the heads of state, the leaders of the Muslim Community of Albania, H. Sabri Koçi in 1993 and H. Skender Bruçaj in 2014, Orthodox leader Archbishop Anastasios Yannoulatos and Bektashi leaders H. Dede Reshat Bardhi in 1993 and H. Dede Edmond Brahimaj in 2014 welcomed Popes.

While Pope Francis, during his visit to Albania in 2014, said:

There is a rather beautiful characteristic of Albania, one which is given great care and attention, and which gives me great joy: I am referring to the peaceful co-existence and collaboration that exists among followers of different religions. The climate of respect and mutual trust between Catholics, Orthodox and Muslims is a precious gift to the country. This is especially the case in these times where an authentic religious spirit is being perverted and where religious differences are being distorted and instrumentalised by extremist groups. This creates dangerous circumstances which lead to conflict and violence, rather than being an occasion for open and respectful dialogue, and for a collective reflection on what it means to believe in God and to follow his laws (as cited in Brown, 2018, p. 20).

\footnotetext{
${ }^{13}$ H. Sabri Koçi (1921 - 2004) was the first Head of Muslim Community of Albania after communism (1990 - 2003). ${ }^{14} \mathrm{https} / / /$ www.youtube.com/watch?v=M5gYVdWn0cU (Muslim Community of Albania Official YouTube Page, Feb 26, 2016)
} 
Brahimaj (2018) emphasizes that this great appreciation for a small nation, remains undoubtedly a special honor, as well as an obligation to preserve and further develop the religious brotherhood, to protect it from any extremism of the time. While when U.S. President George W. Bush visited Albania in 2007, he before his arrival, declared, "I will visit a Muslim majority country coexisting in peace with all religious groups" (Gjana, 2020). Doci (2017) analyzed the case of interreligious harmony in Malbardh, a village in Albania, where "religious tolerance between Christians and Muslims in the village is expressed unmistakably in the building of a Catholic church with the enthusiastic participation of the Muslim majority population in the village" (p. 6). During those years, besides the religious communities have been established three theological schools, Catholic, Orthodox, and Islamic. The Muslim Community of Albania established in 2011 the school of Islamic Theology known as the Department of Islamic Sciences at Bedër University College. During the last decade by the professors and students of the three theological schools have successfully held many visits, mutual meetings, seminars and open lectures. Once every six months, gatherings and symposia with common themes are organized in one of the three, highlevel theological schools.

So far, have been held nine interreligious symposiums on topics such as "Freedom of Religion and Interreligious Dialogue", "Creation", "Family in Islam and Christianity", "Role of Women in Religious Communities", "Divine Love", "Prayer", etc. In one of these symposiums in 2018, Muslim, Catholic, and Orthodox students gathered with their professors chose one representative of each religion and prayed for peace, prosperity, more love for society and each other to provide social well-being and happiness. Interfaith dialogue is not only part of the curricula of these schools but also a practical part of inter-institutional cooperation. Educational and religious institutions in the Balkans should greatly promote a culture of interfaith and interethnic dialogue and tolerance. Other positive examples are provided in the study of Beljanski and Bukvić (2020) on the education of tolerance in Bosnia and Serbia. According to this study, some state universities included subjects of education and intercultural dialogue, examples that remain few compared to the need for peace education in the Balkan area, where wars and conflicts have not been absent (Bakalar, 2018; Beljanski \& Bukvić, 2020). Yannoulatos (2018) highlights we promoted a constructive "dialogue of life", among the various religious communities, cooperating towards environmental protection, reduction of poverty, development, and reconciliation of persons and peoples of the Balkans... we aim to help in Albania's advancement through the growth of justice and social progress (p. 26).

Thus, educational and academic institutions are playing an important role in strengthening interfaith dialogue and its transmission to young people. Thanks to this model in Albania, some European universities are officially cooperating to take Albania as a model. Some examples are the master's program on Interfaith Dialogue of the University of San Marino in partnership with the Department of Islamic Sciences at Bedër University; the organization of international conferences between three universities of religious communities ${ }^{15}$ in Albania, in collaboration with the University of Vienna ${ }^{16}$; the summer school of interfaith dialogue organized by Potsdam University in Albania, etc.

The Interreligious Council of Albania ${ }^{17}$ is also playing an important role by strengthening the role of youth and women in promoting interfaith dialogue in Albania, developments. These developments in Albania have also been emphasized by the largest peace organization "Religions

\footnotetext{
${ }^{15}$ Bedër University (Muslim Community), the Catholic University "Lady of Good Counsel" and "Logos University" (Orthodox University).

${ }^{16}$ Zani i Naltë. http://zaninalte.al/2018/05/zhvillohet-konferenca-nderkombetare-mbi-dialogun-nderfetar-icid/

${ }^{17}$ Interreligious Council of Albania. http://knfsh.al/en/
} 
for Peace." 18 The role of women in the fight against extremism and radicalism is already very important. Karam (2018) also points out this role in a study regarding the contribution of women in interfaith dialogue. These experiences and collaborations have made interfaith dialogue in Albania a model in the international arena. One of the results of these is the international award "Sergio de Mello" given to Interreligious Council of Albania (IRCA) in Poland. ${ }^{19}$

For 2019, the head of IRCA was Archbishop Anastasios, who at the X World Assembly of the "Religions for Peace" held in Lindau, Germany was re-elected as Honorary President of RfP. For 2020, the Presidency of IRCA is headed by Mons. George Frendo, who has also been appointed this year a member of the Pontifical Council for Interreligious Dialogue over the next five years. These are some of the many examples of international assessments of the model of interfaith dialogue in Albania.

Frendo (2018) argues that religious pluralism has not created problems of hostility in Albania, not because Albanians are less religious than other peoples are, or because religion for Albanians is something marginal. Good interfaith relations are a consequence of two factors: (1) because beliefs, by their very nature, are for peace, solidarity, and brotherly love; (2) Albanian politicians have not instrumentalized or manipulated the belief in their political ambitions (Frendo, 2018).

\section{Conclusion and Implications}

Everyone should understand, as Albanian Muslims and Christians, that reality and destiny, not only for them but also for the entire world, from the beginning until its end, depending on the variety of beliefs and convictions. Albanians will not have religious divisions as long as they believe that multiple religions are not a disaster and that God Almighty is the same for all Muslims and Christians.

This tradition of religious tolerance among the Albanians is not a product of modern times; it is a tradition that comes from the past centuries. These values, though, are certainly not guaranteed eternally, but must be conserved and maintained inside the people's inherited or acquired mentality. Consequently, this is the way interfaith co-existence and harmony have continued for years in Albania and have lasted until today through many hardships as a great national value of a small population. However, we have an obligation to protect, cultivate, and promote this value.

Small countries such as Albania can contribute through their values to enriching the global society, by creating a rich mosaic of values and cultures that recognize, respect, and develop each other. The country`s geostrategic position and the people`s multi-religious composition, makes us think of a historical destiny predetermined to help mould and mitigate the disagreements between the East and the West and to contribute to the synthesis of civilizations.

Finally, numerous examples coming from the centuries of co-existence and inter-religious harmony of Albanians take on a special importance today. In this time, the world faces conflicts, wars and divisions, in which religion is often politicized for not at all divine purposes. Therefore today, any positive development and model regarding the strengthening of interfaith dialogue somewhere, is taken as an example to be applied everywhere. Thus, Albania, with the model it offers to the world today, shows the positive result to alleviate every problem and to extinguish every conflict, offering co-existence with everyone regardless of religion, ethnicity, and color. The

\footnotetext{
${ }^{18}$ Religions for Peace. https://rfp.org/

${ }^{19}$ Interreligious Council of Albania. http://knfsh.al/knfsh-vleresohet-me-cmimin-de-mellon-per-te-drejtat-e-njeriut/
} 
world today, more than ever needs peace and dialogue. Youth and women, peace education and the role of religious institutions and leaders in promoting interfaith dialogue are of paramount importance.

This study provides theoretical implications in the field of interfaith dialogue as it contributes to the existing literature with a model of harmony, tolerance, collaboration, and value co-creation between different religions becoming an impetus for scholars and researchers. Besides the theoretical implications, this research comes up also with practical implications for policymakers as well as for religious and academic institutions not only in Albania and Balkan regions but also in other Western and Eastern countries. Government should support all forms of dialogue development, investing in this field through a special budget; promoting in the media common messages about dialogue and organizing national and international events about interfaith harmony; publishing studies and research book. On the other side, religious institutions can establish joint interfaith councils to strengthen interfaith dialogue among them further and cooperate through common events and activities. While, public and private academic institutions, not only theological schools, should include interfaith dialogue in their educational curriculum, as well as promote it through the organization of academic conferences to further develop this field of research. Theological schools of different religions should organize summer and winter schools among them not only within the country, but also cooperate and collaborate on a multicounty perspective. Interfaith cooperation between religious and academic institutions is an applicable model for any multi-religious, multi-ethnic, and multicultural society.

\section{References}

Bakalar, B. (2018). Book Review: Justice on both sides: Transforming education through restorative justice. American Journal of Qualitative Research, 2(2), 145-149.

Beljanski, M., \& Bukvić, E. D. (2020). Comparative overview of the presence of intercultural education of teacher trainees in Serbia and Bosnia and Herzegovina. Journal of Ethnic and Cultural Studies, 7(3), 1-16. http://dx.doi.org/10.29333/ejecs/412

Brahimaj, E. (2018). Albania, a model of interfaith harmony for Europe? In Albania, a model of interfaith harmony for Europe? (pp. 32). Bedër Press.

Brown, C. J. (2018). Keynote speech. In Albania, a model of interfaith harmony for Europe? (pp. 20-22). Bedër Press.

Bruçaj, S. (2018). Interreligious dialogue. In Albania, a model of interfaith harmony for Europe? (pp. 23-25). Bedër Press.

Delvina, S. (1998). Pa pavarësi fetare nuk ka pavarësi kombëtare [Without religious independence there is no national independence]. Eurorilindja,

Dervishi, Z. (1999). Sociologji kulture 1 [Sociology of culture 1]. Sh.B. e Librit Universitar.

Doci, Y. H. (2017). Albania's inter-religious harmony and tolerance: The case of Malbardh. Austrian Journal of Humanities and Social Sciences, 5(6), 3-14. https://doi.org/10.20534/AJH-17-5.6-3-14

Durham, E. (1990). Brenga e Ballkanit dhe vepra të tjera [Balkan concerns and other works]. Shtepia Botuese 8 Nëntori.

Fishta, G. (1998). Lahuta e Malcisë. Onufri.

Frendo, G. (2018). Albania, a model of interfaith harmony for Europe? In Albania, a model of interfaith harmony for Europe? (pp. 28). Bedër Press.

Gjana, F. (2020). Interreligious dialogue and its contribution to international security: The case of Albania. In Paths to a culture of tolerance and peace. River Publishers. https://www.riverpublishers.com/book_details.php?book_id=780 
Hysa, E. (2020). Impact of cultural diversity on Western Balkan countries' performance. Journal of Ethnic and Cultural Studies, 7(1), 20-40. http://dx.doi.org/10.29333/ejecs/292

Kaleshi, H. (1957). Mbi jetën dhe veprën e Rexhep Vokës [On the life and work of Rexhep Voka]. Prishtine.

Karam, A. (2018). Azza Karam on the implications of binary framings for western actors. Feminist Dissent, 3, 233-239. https://doi.org/10.31273/fd.n3.2018.377

Knight, E. F., \& Albania, A. (1880). Narrative of recent travel. Sampson Low, Marston, Searle, \& Rivington. https://file.largepdf.com/file/2019/04/09/9590082736.pdf

Konica, F. (2001). Vepra [Works]. Dudaj.

Kruja, G. (2008). Shqiptarët përballë sfidave të mirëkuptimit ndërfetar [Albanians face the challenges of interfaith understanding]. Prizmi.

Kruja, G., \& Alla, I. (2019). Interreligious harmony in Albania as a model for Europe. Cultori Dell' Incontro, 1 (1), 110-120.

Kruja, G., \& Rasha, A. (Eds.). (2015). 100 personalitete shqiptare të kulturës Islame [100 Albanian personalities of Islamic culture] (2nd ed.). Albania Muslim Community Publishing.

Lane, R. W. (1923). Peaks of Shala. Harper \& Brothers.

Luli, F., \& Dizdari, I. (1995). Në kujtim të brezave [In memory of generations]. Shkodër.

Muja, H. (2009). Disa shembuj të tolerancës fetare ndër shqiptarët [Some examples of religious tolerance among Albanians]. Zëri Islam. https://www.zeriislam.com/artikulli.php?id=1017

Noli, F. (1944). Ligjëratë, mbledhur nga L. Dilo [Lecture, collected by L. Dilo]. Tirana.

Ombashi, R. (2020). Historik $i$ shtypit periodik shqiptar [History of the Albanian periodical press]. Bedër Press.

Pirraku, M. (2003). JO Katedrale në emër të shqiptarisë së imagjinuar [NO Cathedral in the name of imagined Albanianism]. Shkrola.

Shpuza, G. (1997). Kongresi Mysliman Shqiptar-1923 [Albanian Muslim Congress-1923]. Kultura Popullore, 18 (1-2).

Shpuza, G. (1999). Millet sistemi çerçevesinde arnavutlarin durumu [Find the frames in the nation system framework] (Osmanli IV ed.). Güler Eren, Yeni Türkiye Yayinlari.

Spahiu, B. (2012). H. Bujar Spahiu, zgjidhet kryetar i Komunitetit Mysliman të Shqipërisë [H. Bujar Spahiu, is elected president of the Muslim Community of Albania]. http://zaninalte.al/2019/03/h-bujar-spahiu-zgjidhet-kryetar-i-komunitetit-mysliman-teshqiperise/

Ulqini, K. (1999). Faktorë kulturorë e fetarë [Cultural and religious factors]. Shkodër.

UNDP (2018). Toleranca Fetare në Shqipëri [Religious tolerance in Albania]. United Nations Development Program. http://idmalbania.org/wp-content/uploads/2018/04/Tolerancafetare-ne-Shqiperi.pdf

Woofter, S. (2019). Book Review: Building Equity: Policies and Practices to Empower All Learners. American Journal of Qualitative Research, 3(1), 136139. https://doi.org/10.29333/ajqr/5815

Xhelili, Q. (1999, November 16-19). Toleranca në marrëdhëniet midis komuniteteve në Shqipëri dhe ndikimi i tyre në jetën shoqërore në periudhën midis dy luftërave botërore [Tolerance in inter-community relations in Albania and their impact on social life in the period between the two world wars] [International symposium]. Krishterimi ndër Shqiptarë [Christianity among Albanians]. Tirana.

Yannoulatos, A. (2018). Albania, a model of interfaith harmony for Europe? In Albania, a model of interfaith harmony for Europe? (pp. 26). Bedër Press. 
Zamputi, I. (n.d.). Dokumente të shek. XVI- XVII për historinë e Shqipërisë. Akademia e Shkencave. Tirana, II. Dok. 24:71 [Documents of the century. XVI- XVII for the history of Albania. Science Academy. Tirana, II. Doc. 24:71].

\section{Notes on Contributors}

Genti Kruja received a bachelor's degree in sociology at Istanbul University, Turkey, and a master's degree in sociology as well as a Ph.D. degree in Philosophy at Tirana University, Albania. During his master's and Ph.D. studies, he researched interfaith and intercultural dialogue. $\mathrm{He}$ has worked as Director of Culture and Inter-Religious Dialogue at Albania's Muslim Community (2010-2016), and he has been the Editor-in-Chief of the journal Zani i Naltë since 2012. Dr. Kruja is also the Secretary-General of the Albania Inter-Religious Council and is Head of the Islamic Science Department and lecturer in Bedër University in Tirana, Albania. He is the author of Albanians Facing the Challenges of Interfaith Understanding. 